\title{
Dieback of Pinus nigra Seedlings Caused by a Strain of Trichoderma viride
}

\author{
M. G. Li Destri Nicosia, S. Mosca, R. Mercurio, and L. Schena, Dipartimento di Agraria, Università degli Studi Mediterranea, Local- \\ ità Feo di Vito, 89122, Reggio Calabria, Italy
}

\begin{abstract}
Li Destri Nicosia, M. G., Mosca, S., Mercurio, R., and Schena, L. 2015. Dieback of Pinus nigra seedlings caused by a strain of Trichoderma viride. Plant Dis. 99:44-49.

Four different fungi (Trichoderma viride, T. harzianum, Phomopsis sp., and Mortierella sp.) were isolated from 6-year-old Pinus nigra plants showing stunting and high incidence of mortality in a reforestation area of the National Park of Abruzzo, Lazio, and Molise (central Italy). Tests conducted on P. nigra revealed the pathogenic behavior of $T$. viride isolates with 30 to $80 \%$ mortality in artificially inoculated 2year-old seedlings. The pathogenicity of these isolates was also observed in 10-year-old $P$. nigra trees and on lemon fruit. This result, in agreement with the constant isolation of $T$. viride from diseased plants,

suggests the possible role of this fungus in the decline of $P$. nigra plants. T. harzianum and two reference isolates of $T$. viridarium and $T$. trixiae did not cause any symptoms, while Phomopsis sp. and Mortierella sp. caused limited necroses around the inoculation point in a few seedlings. Their role in the decline of P. nigra seedlings was considered irrelevant. According to phylogenetic analyses, pathogenic isolates of $T$. viride clustered in a very uniform group containing strains from different geographic origin and hosts, but none previously reported as a biocontrol agent.
\end{abstract}

Mortality of young forest plants transplanted to afforestation sites is a major problem since seedlings are vulnerable to many biotic and abiotic stress factors during their early life stages, especially when wounded during transplanting (32). In particular, transplanted seedlings interact with a plethora of different microorganisms that can greatly influence their field performance. Among others, all fungi colonizing roots have a significant impact on the health and productivity of tree seedlings, as they are able to form beneficial, neutral, or pathogenic types of association $(16,24)$. Soilborne pathogens of the genera Pythium, Rhizoctonia, and Fusarium are generally recognized as the main causal agents of root dieback in conifers $(11,29,30)$. Diseased seedlings commonly appear stunted and impaired in growth with a yellowing canopy, discolored needles, and rotted roots.

As related to beneficial fungi, species of the genus Hypocreal Trichoderma are among the most frequently isolated since they are ubiquitous and strong colonizers of cellulosic materials, which are often associated with the plant rhizosphere. They have been studied for over 70 years because of their beneficial effect on plant productivity that is exerted by a direct competitive action against plant pathogens and by the induction of growth and defense responses in plants $(15,16,18,36)$. Many Trichoderma species and strains have been reported as effective biocontrol agents and some of them have also been utilized to develop commercially available biological pesticides $(4,31,38,47,48,51)$. According to Schuster and Schmoll (47), the most important biocontrol agents belong to the species $T$. harzianum, $T$. atroviride, $T$. virens, and $T$. asperellum.

Although the beneficial role of Trichoderma species on plant growth and production is universally accepted, a few reports also exist relating to a possible negative effect of Trichoderma species on plants. In 1962, Shemakhanova (49) first observed that $T$. viride can depress mycorrhiza formation and seedling growth on woody plants. Subsequently, other studies revealed some negative effects of $T$. viride, including reduced seedling germination, water-soaked lesions on roots and crown, and increased formation of sclerotia in treated soils $(1,12,33,53)$. It has been reported that some strains of

Corresponding author: L. Schena, E-mail: 1schena@unirc.it

Accepted for publication 16 July 2014.

http://dx.doi.org/10.1094/PDIS-04-14-0433-RE

(C) 2015 The American Phytopathological Society
Trichoderma spp. can be pathogenic on herbaceous crops such as maize, alfalfa, pepper, and tomato by producing cell wall degrading enzymes $(9,33)$. A well-known disease caused by $T$. viride is postharvest rotting of lemons known as Trichoderma rot (7). This disease is a relatively minor problem because it grows slowly as compared to Penicillium rots, but it can cause important losses on oranges and lemons stored for a long period (5). Finally, cultivated mushrooms can suffer great losses from Trichoderma infections $(40,47)$.

In winter 2009, 6-year-old seedlings of Pinus nigra transplanted one year before were observed to be in various stages of decline at the Abruzzo, Lazio, and Molise National Park in central Italy. In particular, a very high incidence of diseased seedlings (around 70\% of the plants) was revealed in a rocky slope of approximately 2 ha. Symptoms on affected plants ranged from leaf chlorosis to plant death and were associated to a dark brown discoloration of cortical and external vascular tissues that extended for about 5 to $10 \mathrm{~cm}$ above and below the ground level. The aim of the present study is to identify fungal isolates associated with 6-year-old $P$. nigra transplants and evaluate the pathogenic behavior of $T$. viride isolates, constantly isolated from this host.

\section{Materials and Methods}

Fungal isolates. Fungal isolates investigated in the present study were obtained from 6-year-old $P$. nigra transplants showing various symptoms of disease. Symptomatic crowns and basal stems were collected from 20 live plants representative of an area of approximately 2 ha with a high incidence of disease at the Abruzzo, Lazio, and Molise National Park in central Italy. All samples were maintained in plastic bags at $4^{\circ} \mathrm{C}$ for no more than 2 days before their processing. Collected organs were washed with tap water, surfacesterilized by dipping for $2 \mathrm{~min}$ in a solution containing $2 \%(\mathrm{v} / \mathrm{v})$ Na-hypochlorite and $1 \%(\mathrm{v} / \mathrm{v})$ Tween 80 , rinsed twice with sterile distilled water, and allowed to dry on blotting paper. External cortex tissues were aseptically discarded and internal small fragments of cortex and/or wood ( $\cong 2 \mathrm{~mm}$ ) were removed from symptomatic and surrounding areas and then plated on potato dextrose agar (PDA) amended with streptomycin ( $250 \mathrm{mg} / \mathrm{liter})$ to prevent contamination by bacteria. Plates were incubated at $24^{\circ} \mathrm{C}$ in the dark for 5 to 10 days and developed fungal colonies were singly transferred onto new PDA plates.

Isolates were grouped according to their macroscopic (morphology and growth ratio of colonies) and microscopic characteristics, and representative cultures were stored on PDA slants at $5^{\circ} \mathrm{C}$ for further investigation. 
Two additional reference fungal strains (CBS 101928 and CBS 18979) were purchased from S-KNAW Fungal Biodiversity Centre, Utrecht, Netherlands (CBS) and included in the analyses. Both strains were deposited as $T$. viride, but according to more recent reports and results of the present study, they belong to $T$. viridarium and T. trixiae, respectively (22).

Amplification and sequencing of target genes. The internal transcribed spacer (ITS) regions of the ribosomal DNA (rDNA) were amplified and sequenced from all fungal isolates analyzed in the present study (Table 1). Total fungal DNA was extracted from 50 to $100 \mathrm{mg}$ of mycelium as described by Schena et al. (41) and amplified with the universal primers ITS5 and ITS4 (54). PCR reactions were performed in a total volume of $25 \mu$ l containing 100 ng of target DNA, $2 \mathrm{mM} \mathrm{MgCl} 2,0.8 \mathrm{mM}$ dNTPs, $0.4 \mathrm{mM}$ of each primer, and $1 \mathrm{U}$ of Taq DNA polymerase (Eurotaq, Heidelberg, Germany). Reactions were incubated in a thermal cycler (Celbio, Hybaid PCR express, Celbio, Milan, Italy) and consisted in 3 min at $94^{\circ} \mathrm{C}$ followed by 35 cycles of $30 \mathrm{~s}$ at $94^{\circ} \mathrm{C}, 30 \mathrm{~s}$ at $55^{\circ} \mathrm{C}$, and 30 $\mathrm{s}$ at $72^{\circ} \mathrm{C}$. All reactions ended with a final extension of $5 \mathrm{~min}$ at $72^{\circ} \mathrm{C}$.

Six isolates preliminarily identified as Trichoderma spp. on the basis of ITS regions were also characterized by amplifying and sequencing the translation elongation factor 1-alpha (tef) gene with primers EF1-728F (2) and TEF1rev (40). Amplification reactions were prepared and incubated as described above for ITS regions.

Amplified products were analyzed by electrophoresis and single bands of the expected size ( $\cong 650$ and 600 bp for ITS and tef gene, respectively) were purified with the QIAquick PCR purification kit (Qiagen, Dusseldorf, Germany) and sequenced with both forward and reverse primers by Macrogen Europe (Amsterdam, Netherlands). ChromasPro version 1.5 software (http://www.technely sium.com.au/) was utilized to evaluate the reliability of sequences and to create consensus sequences. Non-reliable sequences in which either forward or reverse sequences contained doubtful bases were re-sequenced.

Molecular identification and characterization of isolates. All fungal isolates obtained from P. nigra and CBS isolates of T. viridarium and $T$. trixiae were preliminarily identified using ITS sequences as a barcode gene and BLAST to screen sequences from the fungal barcoding project (http://www.fungalbarcoding.org/) and the complete set of GenBank deposited sequences (http://blast.ncbi.nlm.nih.gov/Blast.cgi). To confirm the identity of Trichoderma spp. isolates, ITS sequences were also analyzed using the TrichOKEY 2 program (8).

Furthermore, for a more accurate identification of isolates of Trichoderma spp., sequences of tef were phylogenetically analyzed along with sequences of reference isolates of the T. viride/koningii clade as defined by Jaklitsch et al. $(22,23)$ and Jaklitsch $(20,21)$. Two isolates of T. harzianum obtained in the present study and two reference sequences of this species were utilized as outgroup. Phylogenetic analysis was conducted using maximum likelihood and Bayesian methods. TOPALI v. 2 (http://www.topali.org/) was used to determine the substitution model that best fitted the data. The model HKY $+\mathrm{I}+\mathrm{G}$ was selected for the Bayesian and maximum likelihood phylogenetic analysis using MRBAYES v. 3.1 .1 and PHYML v. 2.4.5, respectively, implemented in TOPALI. Bayesian analysis was performed with four runs conducted simultaneously for 500,000 generations with $10 \%$ sampling frequency and burn in of $30 \%$. Maximum likelihood was performed with 100 bootstrap replicates.

Pathogenicity assays. Experiment 1: tests on 10-year-old $\mathrm{P}$. nigra trees. Preliminary tests were performed on 10-year-old $P$. nigra trees characterized by height and trunk diameter of approximately 170 and $2.5 \mathrm{~cm}$, respectively. Eight isolates representative of all fungi obtained from $P$. nigra in the present study were included in this experiment (Exp. 1; Fig. 1). A cork borer (diameter 6 $\mathrm{mm}$ ) was utilized to remove a disc of bark from the trunk base approximately $10 \mathrm{~cm}$ above soil. Wounds were filled with a plug of PDA of the same shape and size containing actively growing mycelia and enveloped with a strip of Parafilm. Plants mock-inoculated with a PDA plug without mycelium were used as a control. Inoculated plants were kept outside for 2 months (February and January 2011) and occasionally irrigated when natural rain did not occur. Two months after inoculation, a slim layer of external cortex was removed with a scalpel around the inoculation point in order to visualize the presence of necrotic tissues. The area of necrotic lesions was evaluated with the formula of the ellipse using the two perpendicular axes as input data.

To confirm Koch's postulates, inoculated fungi were reisolated from tissues around the inoculation site from a representative number of plants and reidentified by sequencing the ITS regions as described above.

Experiments 2, 3, and 4: tests on 2-year-old P. nigra seedlings. Isolates F120 and F184 identified as T. viride along with isolate F152 identified as T. harzianum and the two CBS isolates of $T$. viridarium (CBS101928) and T. trixiae (CBS189.79) were further assayed for pathogenicity on 2-year-old potted $P$. nigra seedlings

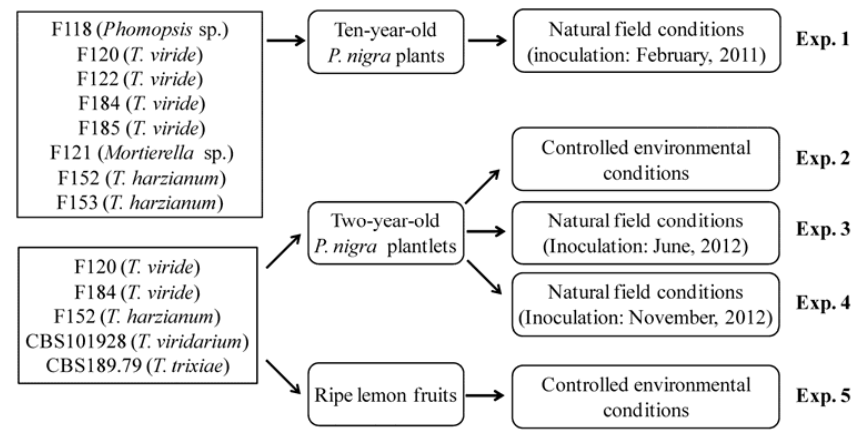

Fig. 1. Summary of trials conducted to evaluate the pathogenicity of fungal isolates obtained from symptomatic trees of Pinus nigra. Two CBS isolates of $T$. viridarium and $T$. trixiae were included in the last four experiments.

Table 1. Fungal isolates analyzed in the present study, their origin, and accession numbers for internal transcribed spacer (ITS) region of the rDNA and translation elongation factor 1-alpha (tef) gene sequences

\begin{tabular}{|c|c|c|c|c|}
\hline \multirow[b]{2}{*}{ Isolate } & \multirow[b]{2}{*}{ Source } & \multirow[b]{2}{*}{ Identified species } & \multicolumn{2}{|c|}{ Accession numbers } \\
\hline & & & ITS & tef \\
\hline F118 & Crown of Pinus nigra & Phomopsis sp. & KJ482538 & n.d. ${ }^{\mathrm{a}}$ \\
\hline F119 & Crown of $P$. nigra & Phomopsis sp. & KJ482539 & n.d. \\
\hline F120 & Crown of $P$. nigra & Trichoderma viride & KJ482541 & KJ482547 \\
\hline F122 & Crown of $P$. nigra & T. viride & KJ482542 & KJ482548 \\
\hline F184 & Crown of $P$. nigra & T. viride & KJ482543 & KJ482549 \\
\hline F185 & Crown of $P$. nigra & T. viride & KJ482544 & KJ482550 \\
\hline F121 & Crown of $P$. nigra & Mortierella sp. & KJ482540 & n.d. \\
\hline F152 & Crown of $P$. nigra & T. harzianum & KJ482536 & KJ531413 \\
\hline F153 & Crown of $P$. nigra & T. harzianum & KJ482537 & KJ531414 \\
\hline CBS101928 & Bark of dead tree & T. viridarium & KJ482545 & KJ482551 \\
\hline CBS189.79 & Decaying wood & T. trixiae & KJ482546 & KJ482552 \\
\hline
\end{tabular}

\footnotetext{
a n.d.: not determined.
} 
under controlled environmental conditions (Exp. 2; Fig. 1). Seedlings were watered every 5 days and maintained in a growth chamber for 2 months with a 12-h photoperiod and constant temperature $\left(19^{\circ} \mathrm{C}\right)$ and relative humidity $(80 \%)$. To inoculate plants, a small downward incision was made at the base of the plant with an angle of 30 degrees in order to lift the bark approximately $3 \mathrm{~mm}$ and allow the introduction of a small disc of PDA $(2 \mathrm{~mm})$ with actively growing mycelium. Inoculated incisions were wrapped in a strip of Parafilm. Plants mock-inoculated with a PDA plug were used as a control.

The same isolates utilized in experiment 2 were further investigated on 2-year-old seedlings as described before but they were kept outside after inoculation and occasionally irrigated when natural rain did not occur. Two additional inoculation experiments were conducted in June (Exp. 3; Fig. 1) and November (Exp. 4; Fig. 1). In experiments 2,3 , and 4 , the percentage of dead seedlings was recorded after 2 months of incubation.

Furthermore, inoculated fungi were reisolated and reidentified as described for experiment 1 to confirm Koch's postulates.

Experiment 5: tests on lemon fruits. Isolates utilized in experiments 2, 3, and 4 were also artificially inoculated on ripe lemon fruits cv Femminello (Exp. 5; Fig. 1). Lemons of uniform size and ripeness were surface sterilized by immersion in a $2 \%$ sodium hypochlorite solution for $2 \mathrm{~min}$, washed twice with tap water, airdried, and wounded in the equatorial zone with a pin (1 $\mathrm{mm}$ diameter). Lemons were inoculated by placing a PDA agar plug $(5 \mathrm{~mm}$ diameter) containing actively growing mycelium on each wound. Lemons mock-inoculated with a sterile agar plug were used as a negative control. The lemons were then mounted on tape strips glued to PVC pads and kept 1 to $2 \mathrm{~cm}$ apart to avoid nesting as described by Schena and co-workers (42). Each PVC pad containing a replication was placed in a proper plastic box covered with a lid and kept at $20^{\circ} \mathrm{C}$ and $95-98 \%$ relative humidity (RH). The percentage of infected wounds was evaluated daily starting 5 days post inoculation.

Experimental design and statistical analyses. All pathogenicity experiments were repeated three times and each repetition con-

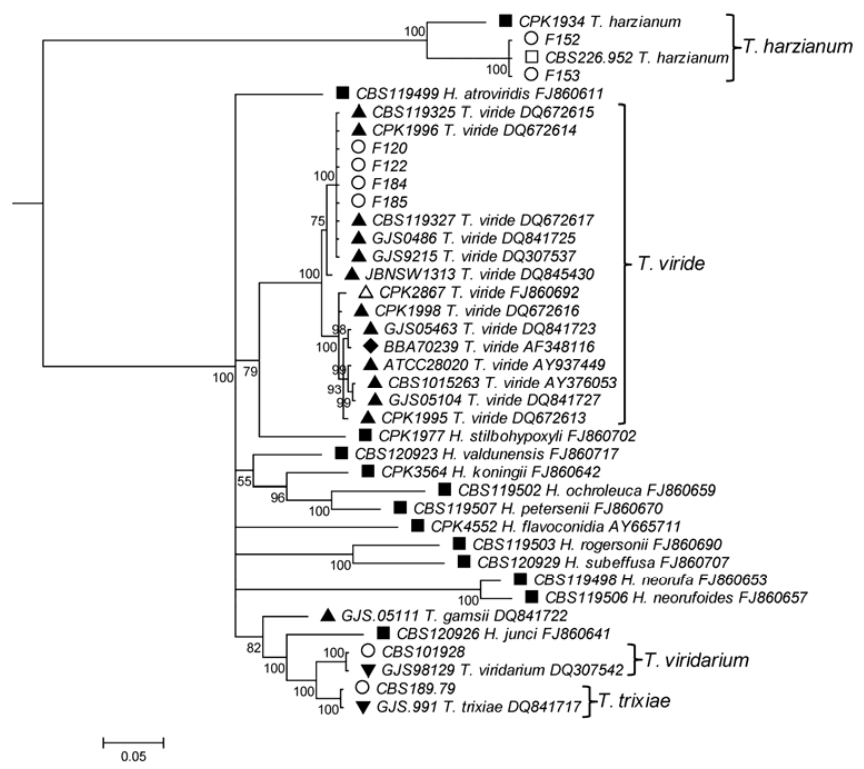

Fig. 2. Phylogenetic tree built using sequences of the tef gene of isolates of Trichoderma harzianum and $T$. viride from Pinus nigra along with CBS isolates of $T$. viridarium (CBS101928) and T. trixiae (CBS189.79) included in pathogenicity test and representative reference sequences of the $T$. viride/koningii clade. Reference sequences were sourced from Jaklitsch et al. (23) $\boldsymbol{\Delta}$, Jaklitsch (21) $\mathbf{\square}$, Jaklitsch (20) $\triangle$, and Jaklitsch et al. (22) $\boldsymbol{\nabla}$. An additional sequence of a biocontrol isolate of $T$. viride $(\checkmark)$ and a sequence of $T$. harzianum $(\square)$ were recovered from Hermosa et al. (17) and Samuels et al. (40), respectively. Isolates characterized in the present study are indicated with the symbol $\bigcirc$. Numbers on nodes represent the statistical support for the Bayesian method. sisted of $10 P$. nigra seedlings or lemon fruits, organized in randomized block design. The data were submitted to the analysis of variance and compared using the Tukey's range test. For experiments 2, 3, and 4, percentages of dead plants were converted into Bliss angular values $(\arcsin \sqrt{ } \%)$ before analysis.

\section{Results}

Fungal isolations. Fungal isolates obtained from symptomatic $P$. nigra seedlings were grouped according to their macroscopic and microscopic characteristics in four different morphotypes. The subsequent molecular characterization of a representative number of isolates from each morphotype enabled the identification of four fungal species: T. viride, Phomopsis sp., T. harzianum, and Mortierella sp. Among these, T. viride was isolated from all assessed seedlings while Phomopsis sp., T. harzianum, and Mortierella sp. were isolated from around 50,20, and 5\% of the analyzed plants, respectively. Other fungal isolates not attributable to any of the above mentioned morphotypes were very rarely isolated and excluded from further investigations.

Fungal identification and characterization. Reliable DNA sequences of the ITS regions were obtained for all isolates recovered from symptomatic $P$. nigra plants. Furthermore, sequences of the tef gene were determined for isolates of Trichoderma spp. obtained in the present study or purchased from CBS. Within each fungal morphotype, representative sequenced isolates had identical ITS and tef sequences. All sequences were deposited in GenBank and accession numbers were assigned (Table 1).

The analysis of the ITS regions with the TrichOKEY 2 program (8) enabled the identification of $T$. viride and $T$. harzianum isolates at the species level. The identities of these isolates were also confirmed by BLAST analysis. In contrast, the TrichOKEY 2 program failed in identifying the two CBS isolates (CBS101928 and CBS189.79) and BLAST analysis enabled their identification only at the genus level since a 99 to $100 \%$ identity was observed in sequences deposited with different Trichoderma spp. names. Similarly, the BLAST analyses enabled the identification of the two remaining morphotypes at the genus level and specifically as Phomopsis sp. and Mortierella sp.

To better identify and characterize isolates of Trichoderma spp., sequences of the tef gene were phylogenetically analyzed along with reference sequences (20-23). MrBayes and PhyML analyses produced trees with a similar topology (Fig. 2). According to the cluster analysis, the identity of isolates preliminarily identified as T. viride and T. harzianum on the base of the ITS analysis was confirmed and a quite high level of genetic diversity with different

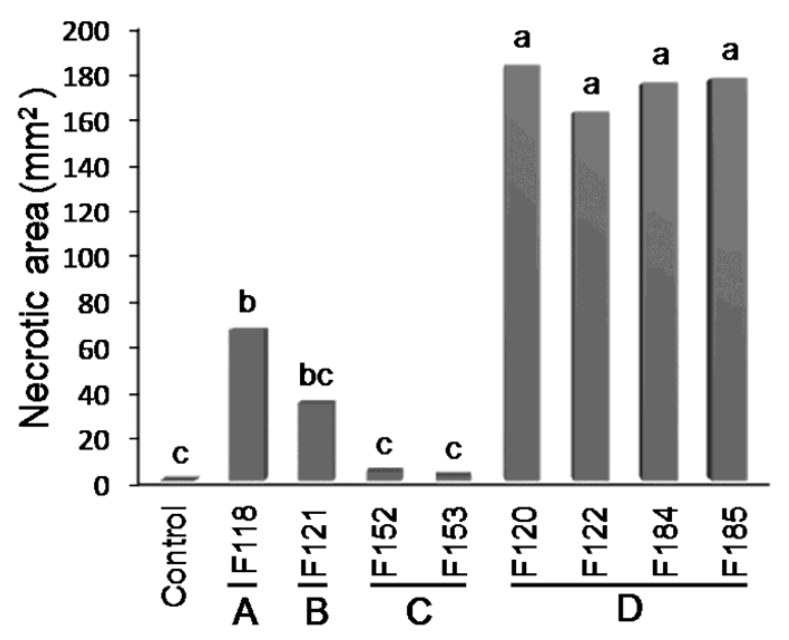

Fig. 3. Extension of necrotic lesions on the stem of 10-year-old potted Pinus nigra plants artificially inoculated in February 2011 with isolates of Phomopsis sp. (A), Mortierella sp. (B), Trichoderma harzianum (C), or T. viride (D) (Cfr. Exp. 1; Fig. 1). A total of 30 seedlings was inoculated per each thesis. Columns with different letters are statistically different according to the Tukey's test $(P \leq 0.05)$. 
bootstrap supported groups was identified in T. viride (Fig. 2). In particular, isolates of this latter species constituted a very uniform group along with different reference strains from various matrices and localities including peat in Canada (strain GJS92-15), Acer pseudoplatanus in the United Kingdom (strain CPK1996), peat in Italy (strain GJS04-86), Picea abies in Australia (strain CBS119327), and $P$. abies in the Czech Republic (strain CBS119325). The two CBS isolates were identified as T. viridarium (CBS 101928) and T. trixiae (CBS 189.79) according to their phylogenetic collocation (Fig. 2).

Pathogenicity assays. Experiment 1: tests on 10-year-old $\mathrm{P}$. nigra trees. In preliminary tests, all isolates of $T$. viride caused subcortical necrotic lesions around the inoculation point with an average extension ranging from 165 to $186 \mathrm{~mm}^{2}$ (Fig. 3). These necrotic lesions were only evident after removing the outer cortex layer with a scalpel, since external tissues only appeared slightly depressed and browned (Fig. 4A). Restricted necrotic areas around the inoculation point were also caused on some inoculated plants by isolate F118 of Phomopsis sp. and to a minor extent by isolate F121 of Mortierella sp. (Fig. 3). In contrast, the tested isolate of $T$. harzianum did not cause any lesion around the inoculation point. None of the inoculated fungi caused evident symptoms of decline on the canopy after 2 months of incubation.

Isolates of $T$. viride were constantly reisolated from all inoculated plants while Phomopsis sp. was reisolated from a restricted number of seedlings showing more evident necrotic lesions. Attempts to reisolate T. harzianum and Mortierella sp. from inoculated plants did not yield positive results.

Experiments 2, 3, 4: tests on 2-year-old P. nigra seedlings. The virulence of isolates F120 and F184 of $T$. viride was confirmed on 2-year-old seedlings of $P$. nigra. In all experiments, inoculated seedlings showed general decline of the canopy consisting of the folding down of needles followed by chlorosis and necrosis, initially localized on the tip and then on the entire needle. Finally, a variable number of seedlings died, according to the experiments (Table 2). Plants that survived remained alive for several months after the end of the trials.

Symptoms around the inoculation point on the stem were very similar to those described above for experiment 1 . The death of the seedlings occurred when the entire stem was girdled (Fig. 4B and C).

Significant differences in terms of percentage of seedlings were observed in the three experiments (Table 2). In controlled environmental conditions (Exp. 2), 80 and $70 \%$ of the seedlings inoculated with isolates F120 and F184 died. The incidence of dead seedlings inoculated with the same isolates was much lower in field conditions when experiments were conducted in the summer season (30\%) (Exp. 3), but remained very high (70 and 80\%) when plants were inoculated in November (Exp. 4).
In all experiments, isolates of $T$. harzianum and the two CBS isolates of $T$. viridarium and $T$. trixiae did not cause any significant symptom on the inoculated seedlings.

Isolates F120 and F184 of $T$. viride were constantly reisolated at the end of experiments 2,3 , and 4, while T. harzianum, $T$. viridari$u m$, and T. trixiae species included in pathogenicity tests were not reisolated.

Experiment 5: tests on lemon fruits. Isolates F120 and F184 of T. viride caused the development of typical Trichoderma rots on all inoculated ripe lemon fruits. Initially, fruits became cocoa brown around the inoculation site. Subsequently, the entire surface of the lemons was rotted and covered by white mycelium and masses of green to dark green spores (data not shown). No symptoms were observed on the control fruits and on lemons inoculated with $T$. harzianum, $T$. viridarium, and $T$. trixiae.

\section{Discussion}

In the present study, different fungal isolates from declining $P$. nigra seedlings were molecularly identified as $T$. viride, T. harzianum, Phomopsis sp., and Mortierella sp. The ITS region of the rDNA was used for the basic identification of isolates since this region is the official fungal DNA barcode marker for fungi and has been utilized to develop TrichOKEY v. 2, a DNA oligonucliotide BarCode program for the identification of multiple sequences of Trichoderma/Hypocrea based on diagnostic hallmarks $(8,43)$. The lack of validated ITS barcode sequences did not enable the identification of Phomopsis sp. and Mortierella sp. at the species level. However, the availability in GenBank of several ITS sequences with very high identities (99 to $100 \%$ ) should have guaranteed a reliable identification of these fungi, at least at the genus level. In both cases, great precaution was taken in the identification process

Table 2. Percentage of Pinus nigra seedlings killed with 2 months of inoculation with Trichoderma species in controlled environmental conditions (Exp. 2) or in field conditions in June (Exp. 3) and November (Exp. 4), 2012 (Cfr. Fig. 1). In all experiments, plantlets mock inoculated with plugs of PDA were used as control. Values sharing common letters in the same column do not differ significantly according to Tukey's test $(P \leq 0.01)$

\begin{tabular}{llccc}
\hline & & \multicolumn{3}{c}{$\%$ of dead plants $^{\mathbf{a}}$} \\
\cline { 3 - 5 } Isolates & \multicolumn{1}{c}{ Species } & Exp. 2 & Exp. 3 & Exp. 4 \\
\hline F120 & Trichoderma viride & $80 \mathrm{~A}$ & $30 \mathrm{~A}$ & $70 \mathrm{~A}$ \\
F184 & T. viride & $70 \mathrm{~A}$ & $30 \mathrm{~A}$ & $80 \mathrm{~A}$ \\
F152 & T. harzianum & $0 \mathrm{~B}$ & $0 \mathrm{~B}$ & $0 \mathrm{~B}$ \\
CBS101928 & T. viridarium & 0 B & $0 \mathrm{~B}$ & $0 \mathrm{~B}$ \\
CBS189.79 & T. trixiae & 0 B & 0 B & $0 \mathrm{~B}$ \\
Control & & 0 B & 0 B & $0 \mathrm{~B}$ \\
\hline
\end{tabular}

a A total of 30 seedlings was inoculated per each thesis.
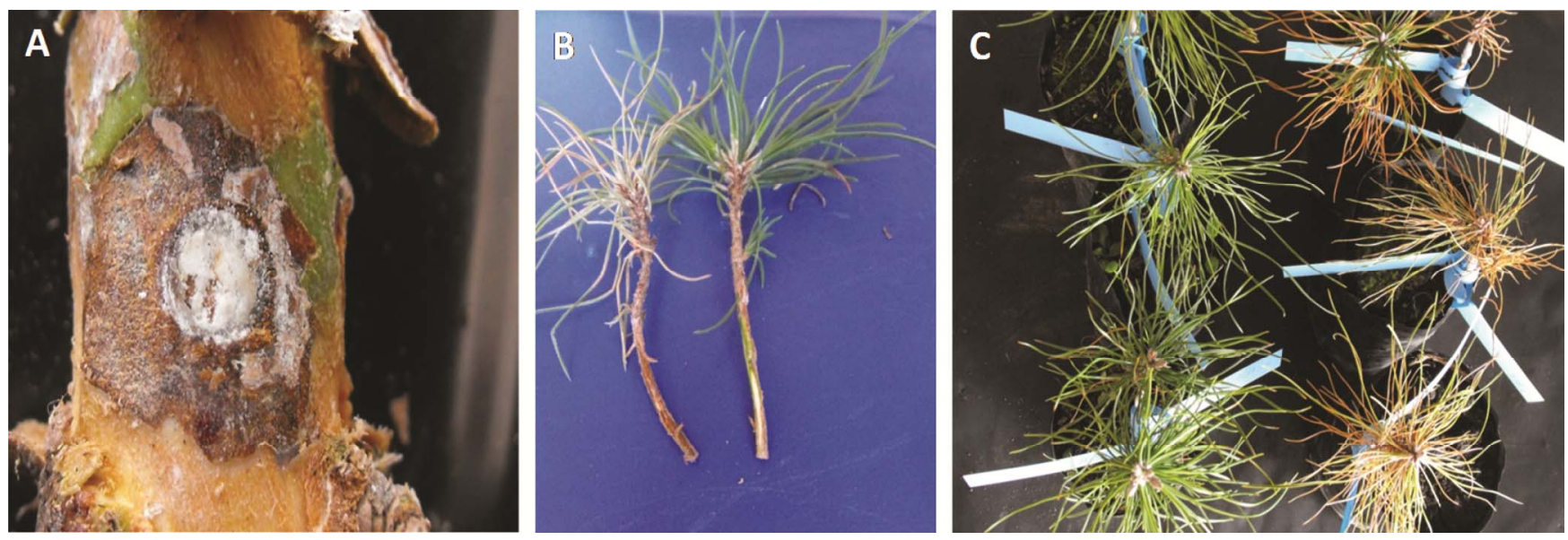

Fig. 4. Symptoms on Pinus nigra plants artificially inoculated with isolate F120 of Trichoderma viride. A, Sub-cortical necrotic lesions on the stem of a 10-year-old $P$. nigra plant after two months of incubation in field conditions (Cfr. Exp. 1; Fig. 1). B, Necroses on stem and canopy of a seedling inoculated in controlled environmental conditions (left) as compared with a healthy plant mock-inoculated with a plug of PDA medium (right) (Cfr. Exp. 2; Fig. 1). C, Two-year-old $P$. nigra seedlings inoculated in November 2012 (right) as compared with control plants mock-inoculated with plugs of PDA medium (left side) (Cfr. Exp. 4; Fig. 2). 
because of unreliable annotations of sequences in public DNA repositories, which remain an obstacle to all sequence-based species identifications (37).

In the case of Trichoderma spp., the polymorphism within the ITS region enabled the identification of T. viride and T. harzianum using the TrichOKEY program but failed in identifying the two reference isolates, both erroneously deposited as $T$. viride in CBS. One of these isolates (CBS101928) has been recently reclassified as $T$. viridarium (22), while the other one (CBS189.79) is still (as of March 2014) reported as T. viride. This latter isolate was identified as T. trixiae according to its phylogenetic analysis along with validated barcoding sequences of the tef gene (22). Furthermore, the tef gene was a valuable marker to determine the genetic diversity among isolates of $T$. viride, which are characterized by identical ITS sequences (23).

Fungal isolates characterized in the present study were obtained from P. nigra seedlings in a reforestation area of the National Park of Abruzzo, Lazio, and Molise showing stunting and high incidence of mortality. Among identified fungi, Phomopsis and Mortierella isolates caused very limited necroses around the inoculation point in artificially inoculated plants. These fungal genera are ubiquitous in soil and have been frequently found on woody plants in forests. Mortierella spp. are root-colonizing fungi that show weak pathogenicity on conifer seedlings under natural conditions $(10,46)$. Similarly, Phomopsis species are common minor pathogens associated with the roots and canopy of many species of forestal woody plants including conifers $(13,52)$. They mainly attack weakened plants as a consequence of frost injury or damage $(3,14)$.

As regards to Trichoderma spp., the two CBS isolates of $T$. viridarium and T. trixiae and isolates of $T$. harzianum did not cause any symptoms on inoculated $P$. nigra seedlings or on lemon fruits. Isolates of $T$. viride proved to be pathogens in all tests, although the level of virulence was significantly influenced by the age of the host and the environmental conditions. Indeed, when $T$. viride was inoculated on 10-year-old trees, extended necroses developed around the inoculation site, but lesions remained localized and no evident symptoms were observed on the canopy, probably because plants reacted blocking the fungus thus avoiding that the stem was girdled. On the contrary, when $T$. viride isolates were inoculated on 2-year-old seedlings, the percentage of seedlings killed by the fungus ranged from 30 to $80 \%$, even though the stems of these seedlings were already lignified. In general, the death of plants occurred when necroses diffused to the entire stem circumference of the stem and was preceded by general symptoms of decline on the canopy consisting of folding down of needles followed by chlorosis and necrosis, initially localized on the tips and then on entire pine needles. Interestingly, the incidence of dead seedlings was sharply influenced by the environmental condition being lower (30\%) when seedlings were inoculated in June (dry and hot season) and much higher $(80 \%)$ when seedlings were inoculated in November. The mild average temperature $\left(16^{\circ} \mathrm{C}\right)$ and the high incidence of rainfall $(190 \mathrm{~mm})$ recorded in November and December 2012 in the experimentation area may have greatly favored the development of the disease. In agreement, the same incidence of dead seedlings $(80 \%)$ was obtained in controlled environmental conditions set up to have high relative humidity and a constant temperature of $19^{\circ} \mathrm{C}$.

The pathogenic behavior of $T$. viride isolates characterized in this study was undoubtedly demonstrated. Although available data obtained by artificial inoculation of wounded plants does not seem enough to assert that $T$. viride was the primary cause of the decline of P. nigra transplants in the National Park of Abruzzo, Lazio, and Molise, this pathogen surely contributed to their decay. Since plants had been transplanted only one year before, it can be hypothesized that stress factors related to transplanting significantly favored attacks by $T$. viride $(19,27,50)$. It is a fact that $T$. viride was the only fungus always associated with the declining plants. On the other hand, the role of the other fungi isolated from $P$. nigra seemed to be of secondary importance (Phomopsis spp.) or completely irrelevant (Mortierella spp.) based on the low level of path- ogenicity revealed on artificially inoculated plants and their occasional isolation from diseased plants.

The identification of $T$. viride as a plant pathogen is not completely novel but, to the best of our knowledge, the present study represents the first clear evidence of pathogenicity on lignified conifer plants. Previous studies have been exclusively conducted in artificial experimental conditions, most providing the in vitro inoculation of the fungus on germinated seedlings $(10,34,44)$. Several studies investigated root penetration by Trichoderma species in young conifer seedlings and some of them hypothesized that Trichoderma species can be pathogens of conifers and play a role in the decline of forests in central Europe $(6,10,25-27,34,44-46)$. The suppression of seed germination and seedling growth was also observed after inoculation of $T$. viride and $T$. harzianum on wheat, cucumber, tomato, and pepper $(33,52)$. According to Vujanovic and co-workers (52), this effect may be caused by mycotoxins produced by Trichoderma species.

The detected pathogenic behavior of $T$. viride seems to be in contrast with the huge amount of reports indicating Trichoderma species as avirulent plant symbionts or as parasites of other fungi (16). However, given the very complex taxonomy and continuous revision of this genus, it is likely that there has been some misidentification, which may be the key understanding different behavior of Trichoderma species or strains (20-22). The genetic characterization of 69 biocontrol agents of Trichoderma spp. revealed the incorrect identification of many isolates, including six erroneously assigned to the species $T$. viride (17). Three biocontrol agents (ATCC36042, ATCC52439, and ATCC52442) previously identified as $T$. viride were recently reclassified as $T$. asperelloides (39). The most widely used commercial biofungicide in India has been demonstrated to contain $T$. asperelloides and not $T$. viride as previously reported (35). Similarly, one of the two Trichoderma species contained in a bioformulate registered in Italy with the commercial name "Remedier," was until recently registered as T. viride, but it is actually T. gamsii (http://www.sumitomo-chem.it/scheda_prodotto/ 13/Remedier).

A direct consequence of the taxonomy revision of the genus Trichoderma is that the role of $T$. viride as biocontrol agent has been significantly downgraded (47). Among the 69 biocontrol agents reported by Hermosa and coworkers (17), only two (BBA70239 and GJS89-142) were identified as T. viride. Furthermore, the phylogenetic analysis conducted in the present study using the tef gene revealed a high level of genetic diversity within T. viride as defined by Jaklitsch et al. (23), with pathogenic isolates clustering in a very uniform group containing strains from different geographic origin and hosts (Fig. 2). According to available data, none of these isolates has been investigated as a biocontrol agent (23). This may suggest that the pathogenic behavior is restricted to a specific molecular clade of $T$. viride. Additional specific investigations are needed to confirm this hypothesis and to determine if isolates of $T$. viride that cause post-harvest rot in citrus are genetically related to the pathogenic isolates characterized in the present study.

\section{Literature Cited}

1. Beily, B. A., and Lumsden, R. D. 1998. Direct effects of Trichoderma and Gliocladium on plant growth and resistance to pathogens. Pages 185-204 in: Trichoderma and Gliocladium: enzymes, biological control, and commercial applications, vol. 2. C. P. Kubicek, G. E. Harman, and K. L. Ondik, eds CRC Press, New York.

2. Carbone, I., and Kohn, L. M. 1999. A method for designing primer sets for speciation studies in filamentous ascomycetes. Mycologia 91:553-556.

3. Cech, T. L. 2000. Fungal diseases associated with artificial stand establishment. Forstschutz Aktuell 25:13-16.

4. Chet, I. 1987. Trichoderma application, mode of action, and potential as a biocontrol agent of soilborne plant pathogenic fungi. Pages 137-160 in: Innovative Approaches to Plant Disease Control. John Wiley \& Sons, New York.

5. Cole, A. L. J., and Wood, R. K. S. 1970. The infection of oranges by Trichoderma viride and mixed infection by Trichoderma viride and Penicillium digitatum. Ann. Appl. Biol. 66:75-82.

6. Dahm, H., Strzelczyk, E., and Manka, M. 1997. Production of cellulolytic and pectolytic enzymes by Fusarium oxysporum (Schlecht.), Rhizoctonia 
solani (Kuhn) and Trichoderma viride (Pers. ex Gray). Phytopathologia Polonica 13:19-30.

7. Dodd, M., Cronje, P., Taylor, M., Huysamer, M., Kruger, F., Lotz, E., and Van Der Merwe, K. 2010. A review of the post harvest handling of fruits in South Africa over the past twenty five years. South Afr. J. Plant Soil: 25th anniversary $27: 97-116$.

8. Druzhinina, I. S., Kopchinskiy, A. G., Komoj, M., Bissett, J., Szakacs, G., and Kubicek, C. P. 2005. An oligonucleotide barcode for species identification in Trichoderma and Hypocrea. Fungal Genet. Biol. 42:813-828.

9. Farr, D. F., Bills, G. F., Chamuris, G. P., and Rossman, A. Y. 1989. Fungi on plants and plant products in the United States. APS Press, St. Paul, MN.

10. Forbrig, R. 1989. Anatomical and histological investigations on fungusinfected Norway spruce (Picea abies) seedlings. Allg. Forst Jagdztg. 160:137-144.

11. Galaaen, R, and Venn, K. 1979. Pythium sylvaticum Campbell \& Hendrix and other fungi associated with root dieback of 2-0 seedlings of Picea abies (L.) Karst. in Norway. Meddelelser fra Norsk Institutt for Skogforskning 34:265-280.

12. Gerlagh, M., Goossen-van de Geijn, H. M., Fokkema, N. J., and Vereijken, P. F. G. 1999. Long-term biosanitation by application of Coniothyrium minitans on Sclerotinia sclerotiorum-infected crops. Phytopathology 89:141-147.

13. Girlanda, M., Ghignone, S., and Luppi, A. M. 2002. Diversity of sterile root-associated fungi of two Mediterranean plants. New Phytol. 155:481498.

14. Gomes, R. R., Glienke, C., Videira S. I. R., Lombard, L., Groenewald, J. Z., and Crous, P. W. 2013. Diaporthe: a genus of endophytic, saprobic and plant pathogenic fungi. Persoonia 31:1-41.

15. Harman, G. E. 2000. Myths and dogmas of biocontrol. Changes in perceptions derived from research on Trichoderma harzianum T22. Plant Dis. $84: 377-393$.

16. Harman, G. E., Howell, C. R., Viterbo, A., Chet I., and Lorito, M. 2004. Trichoderma species - opportunistics, avirulent plant symbionts. Microbiology 2:43-56.

17. Hermosa, M. R., Keck., E., Chamorro, I., Rubio, B., Sanz, L., Vizcaino, J. A., Grondona, I., and Monte, E. 2004. Genetic diversity shown in Trichoderma biocontrol isolates. Mycol. Res. 108:897-906.

18. Hjeljord, L., and Tronsmo, A. 1998. Trichoderma and Gliocladium in biocontrol: an overview. Pages 135-151 in: Trichoderma and Gliocladium, C. P. Kubicek and G. E. Harman, eds. Taylor \& Francis, Ltd., London.

19. Jackson, D. P., Enebak, S. A., and South, D. B. 2012. Survival of southern pine seedlings after inoculations with Pythium and cold storage in the presence of peat moss. Forest Pathol. 42:44-51.

20. Jaklitsch, J. W. M. 2011. European species of Hypocrea part II: species with hyaline Ascospores. Fungal Divers. 48:1-250.

21. Jaklitsch, J. W. M. 2009. European species of Hypocrea Part I. The greenspored species. Stud. Mycol. 63:1-91.

22. Jaklitsch, W. M., Samuels, G. J., Ismaiel, A., and Voglmayr, H. 2013. Disentangling the Trichoderma viridescens complex. Persoonia 31:112-146.

23. Jaklitsch, W. M., Samuels, G. J., Dodd, S. L., Lu, B. S., and Druzhinina, I. S. 2006. Hypocrea rufa/Trichoderma viride: a reassessment, and description of five closely related species with and without warted conidia. Stud. Mycol. 55:135-177.

24. Jumpponen, A., and Trappe, J. M. 1998. Dark septate endophytes: a review of facultative biotrophic root-colonizing fungi. New Phytol. 140:295-310.

25. Kattner, D. 1990. Zur Pathogenität von Trichoderma hamatum (Bon.) Bain an Fichtenkeimlin-gen (Picea abies Karst,). Allg. Forst Jagdztg. 161:1-6.

26. Kattner, D. 1991. Zur Pathogenität Von Trichoderma polysporum (Rifai) Bain an Fichtenkeimlingen (Picea abies Karst.). Allg. Forst Jagdztg. 162:60-62.

27. Kattner, D. 1992. Der EinfluB von TrockenstreB auf die Besiedelung von Fichtenfeinwurzeln (Picea abies Karst.) dutch Trichoderma viride und andere endophytische Mikropilze. Forstwiss Centralbl 111:383-389.

28. Kiss, L. 2012. Limits of nuclear ribosomal DNA internal transcribed spacer (ITS) sequences as species barcodes for Fungi. Proc. Natl. Acad. Sci. USA 109:E1811.

29. Lilja, A., and Rikala, R., 2000. Effect of uninucleate Rhizoctonia on the survival of outplanted Scots pine and Norway spruce seedlings. Forest Pathol. 30:109-115.

30. Lilja, A., Lilja, S., Poteri, M., and Ziren, L. 1992. Conifer seedling root fungi and root dieback in Finnish nurseries. Scand. J. Forest Res. 7:547556.
31. Lorito, M., Hayes, C. K., Zoina, A., Scala, F., Del Sorbo, G., Woo, S. L., and Harman, G. E. 1994. Potential of genes and gene products from Trichoderma sp. and Gliocladium sp. for the development of biological pesticides. Mol. Biotechnol. 2:209-217.

32. Mckay, H. M. 1996. A review of the effect of stresses between lifting and planting on nursery stock quality and performance. New Forest 13:363-393.

33. Menzies, J. G. 1993. A strain of Trichoderma viride pathogenic to germinating seedlings of cucumber, pepper and tomato. Plant Pathol. 42:784-791.

34. Mittal, R. K., and Wang, B. S. P. 1993. Effects of some seed-borne fungi on Picea glauca and Pinus strobus seeds. Eur. J. Forest Pathol. 23:138-146.

35. Mukherjee, P. K., Mukherjee, A. K., Kranthi, S. 2013. Reclassification of Trichoderma viride (TNAU), the most widely used commercial biofungicide in India, as Trichoderma asperelloides. The Open Biotechnol. J. 7:7-9.

36. Nawrocka, J., and Małolepsza, U. 2013. Diversity in plant systemic resistance induced by Trichoderma. Biol. Control 67:149-156.

37. Nilsson, R. H., Ryberg, M., Kristiansson, E., Abarenkov, K., Larsson, K. H., and Koljalg, U. 2006. Taxonomic reliability of DNA sequences in public sequence databases: a fungal perspective. PLoS ONE 1:e59.

38. Papavizas, G. C. 1985. Trichoderma and Gliocladium: biology, ecology and potential for biocontrol. Annu. Rev. Phythopathol. 23:23-54.

39. Samuels, G. J. 2010. Trichoderma asperellum sensu lato consists of two cryptic species. Mycologia 102:944-966.

40. Samuels, G. J., Dodd, S. L., Gams, W., Castlebury, L. A., Petrini, O. 2002. Trichoderma species associated with the green mold epidemic of commercially grown Agaricus bisporus. Mycologia 94:146-170.

41. Schena, L., and Cooke, D. E. L. 2006. Assessing the potential of regions of the nuclear and mitochondrial genome to develop a "molecular tool box" for the detection and characterization of Phytophthora species. J. Microbiol. Meth. 67:80-85

42. Schena, L., Ippolito, A., Zahavi, T., Cohen, L., and Droby, S. 2000. Molecular approaches to assist the screening and monitoring of postharvest biocontrol yeasts. Eur. J. Plant Pathol. 106:681-691.

43. Schoch, C. L., Seifert, K. A., Huhndorf, S., Robert, V., Spouge, J. L., Levesque, L. V., Chen, W., and Fungal Barcoding Consortium. 2012. Nuclear ribosomal internal transcribed spacer (ITS) region as a universal DNA barcode marker for Fungi. Proc. Natl. Acad. Sci. U.S.A. 109:6241-6246.

44. Schönhar, S. 1984. Infection tests on spruce and pine seedlings with fungi frequently isolated from deteriorated roots of conifers. [Infektionsversuche an Fichtenund Kiefernkeimlingen mit aus faulen Feinwurzeln von Nadelbäumen häufig isolierten Pilzen]. Allg. Forst. Jagdztg. 155:191-192.

45. Schönhar, S. 1989. Infection tests on Norway spruce seedlings with fungi isolated from damaged fine roots of spruce. Allg. Forst Jagdztg. 160:98-99.

46. Schönhar, S. 1991. Infection tests on Norway spruce seedlings with root fungi on soil substrates having strongly acid and neutral reactions. Allg. Forst Jagdztg. 162:134-136.

47. Schuster, A., and Schmoll, M. 2010. Biology and biotechnology of Trichoderma. App. Microbiol. Biot. 87:787-799.

48. Sharma, K., Mishra, A. K., and Misra, R. S. 2009. Morphological, biochemical and molecular characterization of Trichoderma harzianum isolates for their efficiency as biological control agents. J. Phytopathol. 157:51-56.

49. Shemakhanova, N. M. 1962. Mycotrophy of woody plants. Translated by US Dept. of Agriculture and the National Science Foundation, Washington, D. C., Israel Program for Scientific Translations 1967. (orig. Mikotrofiya drevesnykh porod. Institut Mikrobiologii, Akademiya Nauk SSSR, Moscow).

50. Summerbell, R. C. 2005. From Lamarckian fertilizers to fungal castles: recapturing the pre-1985 literature on endophytic and saprotrophic fungi associated with ectomycorrhizal root systems. Stud. Mycol. 53:191-256.

51. Verma, M., Brar, S. K., Tyagi,. Surampalli, R. Y., and Valéro, J. R. 2007. Antagonistic fungi, Trichoderma spp.: Panoply of biological control. Biochem. Eng. J. 37:1-20.

52. Vujanovic, V., St-Arnaud, M., and Neumann, P. J. 2000. Susceptibility of cones and seeds to fungal infection in a pine collection. Forest Pathol. 30:305-320.

53. Vujanovic, V., and Goh, Y. K. 2012. qPCR quantification of Sphaerodes mycoparasitica biotrophic mycoparasite interaction with Fusarium graminearum: in vitro and in planta assays. Arch. Microbiol. 194:707-717.

54. White, T. J., Bruns, T., Lee, S., and Taylor, J. W. 1990. Amplification and direct sequencing of fungal ribosomal RNA genes for phylogenetics. Pages 315-322 in: PCR protocols: a guide to methods and applications eds. M. A Innis, D. H. Gelfand, J. J. Sninsky, and T. J. White, eds. Academic Press, Inc., New York. 